\title{
Ecology and abundance of Bellamya bengalensis (Lamarck, 1822) (Gastropoda:Viviparidae) in pond habitats of Rajshahi
}

\author{
B. K. Saha*, M. S. Jahan and M. A. Hossain \\ Fisheries Research Laboratory, Department of Zoology, Rajshahi University, Rajshahi-6205, Bangladesh
}

\begin{abstract}
Studies on the ecology and abundance of Bellamya bengalensis (Lamarck, 1822) was carried out in Rajshahi University Campus in pond habitat. The physico-chemical parameters viz. water temperature $\left(27.6 \pm 4.23{ }^{\circ} \mathrm{C}\right.$ in 1995 and $27.4 \pm 4.43{ }^{\circ} \mathrm{C}$ in 1996$)$, water transparency $(0.41 \pm 0.03 \mathrm{~cm}$ in 1995 and $0.42 \pm 0.04 \mathrm{~cm}$ in 1996$)$, sunshine $(6.22 \pm 1.98$ hours in 1995 and $7.41 \pm 1.56$ hours in 1996$), \mathrm{pH}(7.78 \pm 0.38$ in 1995 and $7.84 \pm 0.27$ in 1996), DO $\left(4.92 \pm 0.75 \mathrm{mg} / \mathrm{l}\right.$ in 1995 and $5.73 \pm 1.5 \mathrm{mg} / \mathrm{l}$ in 1996) and $\mathrm{CO}_{2}(5.45 \pm 2.06 \mathrm{mg} / \mathrm{l}$ in $1995 \mathrm{and} 4.04 \pm 1.34$ $\mathrm{mg} / \mathrm{l}$ in 1996) of different ponds were recorded.The physico-chemical parameters viz. water temperature $\left(25.82 \pm 4.87{ }^{\circ} \mathrm{C}\right.$ in 1995 and 25.96 $\pm 5.4{ }^{\circ} \mathrm{C}$ in 1996), water transparency $(0.37 \pm 0.02 \mathrm{~cm}$ in 1995 and $0.4 \pm 0.03 \mathrm{~cm}$ in 1996), $\mathrm{pH}(7.78 \pm 0.08$ in 1995 and $7.8 \pm 0.12$ in 1996$)$, DO $\left(3.1 \pm 0.06 \mathrm{mg} / \mathrm{l}\right.$ in 1995 and $2.86 \pm 0.31 \mathrm{mg} / \mathrm{l}$ in 1996) and $\mathrm{CO}_{2}(14.6 \pm 0.76 \mathrm{mg} / \mathrm{l}$ in 1995 and $13.54 \pm 1.53 \mathrm{mg} / \mathrm{l}$ in 1996) of ditches were recorded. The physico-chemical parameters viz. water temperature $\left(30.18 \pm 1.21{ }^{\circ} \mathrm{C}\right.$ in 1995 and $30.07 \pm 1.21{ }^{\circ} \mathrm{C}$ in 1996$)$, $\mathrm{pH}(7.93 \pm 0.3 \mathrm{in}$ 1995 and $7.98 \pm 0.3$ in 1996), $\mathrm{DO}\left(4.93 \pm 0.12 \mathrm{mg} / \mathrm{l}\right.$ in 1995 and $4.97 \pm 0.13 \mathrm{mg} / \mathrm{l}$ in 1996) and $\mathrm{CO}_{2}(5.63 \pm 1.74 \mathrm{mg} / \mathrm{l}$ in $1995 \mathrm{and} 5.57 \pm 1.78$ $\mathrm{mg} / \mathrm{l}$ in 1996) of irrigated paddy field were determined. The rainfall was recorded as $123.36 \pm 127.27 \mathrm{~cm}$ and $105.75 \pm 111.11 \mathrm{~cm}$ during 1995 and 1996, respectively. Thirty five spp. of hydrophytes were identified.The minimum and maximum abundances per $\mathrm{m}^{2}$ were determined as $124.58 \pm 58.93$ and $133.33 \pm 60.84$ during the observation periods of 1995 and 1996, respectively.
\end{abstract}

Key words: Ecology; Bellamya bengalensis; Aquatic vegetation; Abundance; Sunshine; Pond habitat

\section{Introduction}

Freshwater gastropods, which constitute the bulk of littoral fauna of tanks, ponds, beels, reservoirs and rivers, play an important role in the dynamics of aquatic ecosystems. Though viviparids are usually found in stagnant waterbodies, these are also present in irrigated paddy fields and rarely in running water. Prashad (1925), Boycott (1934), and Patnaik and Ray (1968) reported that various snail species occupy different freshwater habitats depending on the mode of their lives requisites.The various physico-chemical factors like sunshine, turbidity, lime content, $\mathrm{pH}$, dissolved oxygen, free carbon dioxide etc. and the aquatic vegetation, substratum have definite interrelated direct or indirect effects on snails and its habitat.

Bangladesh abounds with a large number of rivers, canals, tanks, ponds, ditches, beels and haors. Moreover, cultivable low lands and irrigated paddy fields of the country offer a good habitat for viviparid gastropods. Annandale and Sewell (1921), Michael (1968), Hanifa (1978), Khan and Chaudhuri (1984) and Subba Rao (1989) studied the distribution, bionomics, seasonal variation and population ecology of $B$. bengalensis in some natural and artificial freshwater bodies of West Bengal, India. But in Bangladesh, there is a general lack of information on any gastropod species. Only Ali and Chakraborty (1992), and Jahan (1993) mentioned the taxonomic record, distribution and some ecological notes of few gastropods found in the country.

So, an investigation was conducted to determine ecology and abundance of $B$. bengalensis from different waterbodies of ponds in Rajshahi University campus from January, 1995 to December, 1996.

\section{Material and methods}

Fortnightly (on the 1 st and $15^{\text {th }}$ in each month in ponds and ditches; the $5^{\text {th }}$ and $20^{\text {th }}$ in irrigated paddy fields), water samples were collected from the sampling areas in the morning (8:00 am) and in the afternoon (5:00 pm). Randomly 3 (three) pockets, each of $1 \mathrm{~m}^{2}$ area in every habitat, were demarcated for the collection of snails. The vegetation and the upper most layer of the substratum $(2 \mathrm{~cm})$ were picked up and flooded with water in a tray. Only the live snails were

\footnotetext{
* Corresponding author e-mail: bimalkantasaha@yahoo.com
} 
counted. Mean values of such 3 (three) readings were considered as the actual abundance of $B$. bengalensis population in the waterbodies concerned (Fig. 1).

Water temperatures were measured with the help of a mercury thermometer $\left(-1{ }^{\circ} \mathrm{C}-50{ }^{\circ} \mathrm{C}\right)$ on the sampling spots. The monthly meteorological data on the rainfall and sunshine were collected from the Meteorological Department, Rajshahi. For the chemical analyses, water samples were collected from the sampling areas and brought to the laboratory within short time. $\mathrm{pH}$ of water was measured with the help of water quality checker (WQC-OA, TOA, Japan). Dissolved oxygen (DO) was determined using Alsterber (azide modification of the Winkler method) (APHA, 1989). Dissolved carbon dioxide $\left(\mathrm{CO}_{2}\right)$ was measured by titration with $\mathrm{N} / 44 \mathrm{NaOH}$ solution using phenolphthalein as indicator (Welch, 1948). Different types of hydrophytes were identified following Subramanyam (1962), and Khan and Halim (1987).

\section{Results and discussion}

Ecology

$B$. bengalensis was encountered in the areas under study period in different pond habitats, but the range of tolerance (ecological) was limited. B. bengalensis was invariably found in permanent waterbodies and thus appeared to be a true aquatic form. Clean water rich in aquatic vegetations was the plenty and dominant site. Tanks / ponds with steep edge and deep water having little or no vegetation appeared quite unsuitable and no such snails could be collected. In ditches and irrigated paddy fields, B. bengalensis was almost absent. The snails were found enormous in the stream at the exit of the drainage system.

The physico-chemical conditions of ponds, ditches and irrigated paddy fields more or less varied due to the change of

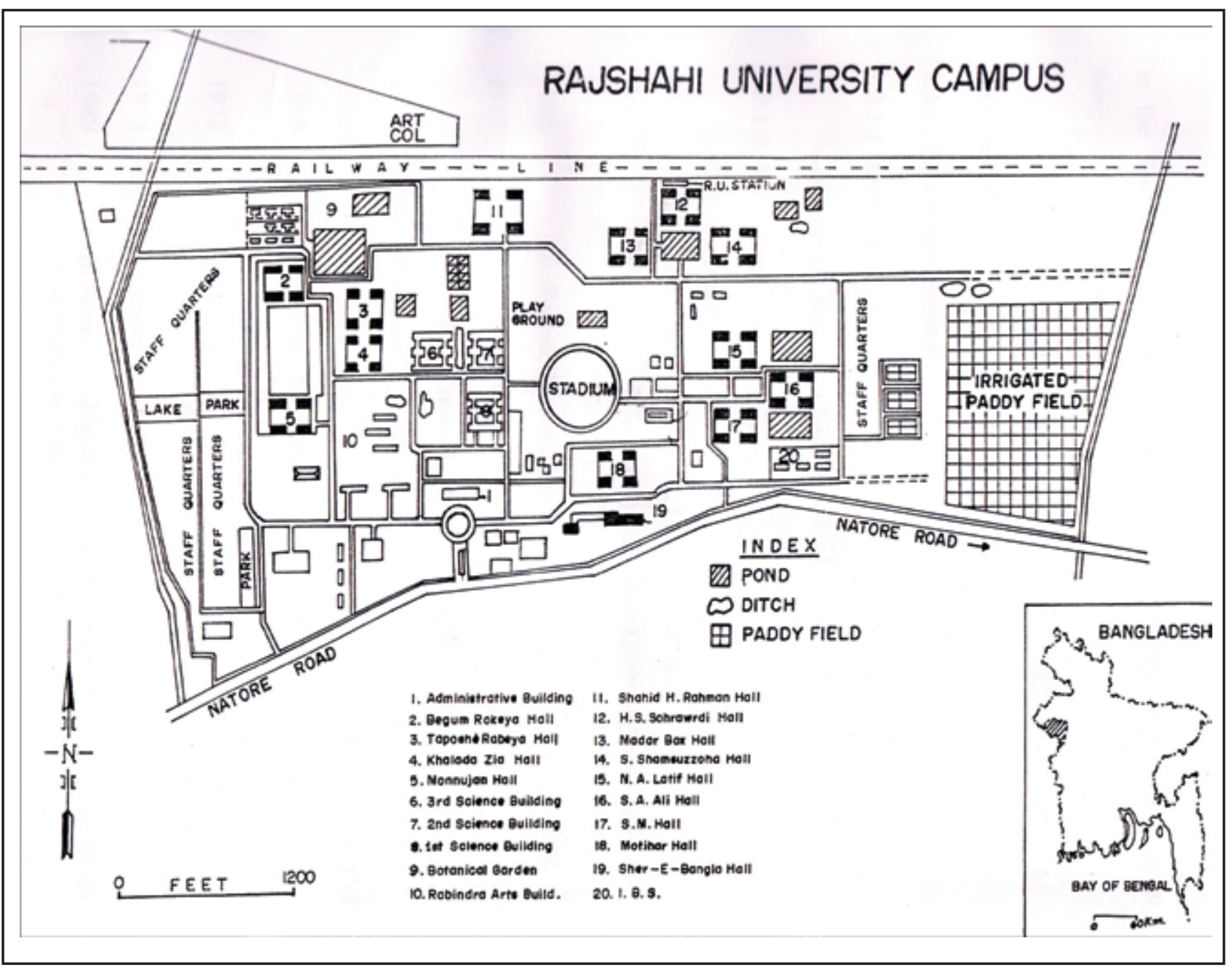

Fig. 1. Rajshahi University Campus showing sampling stations 


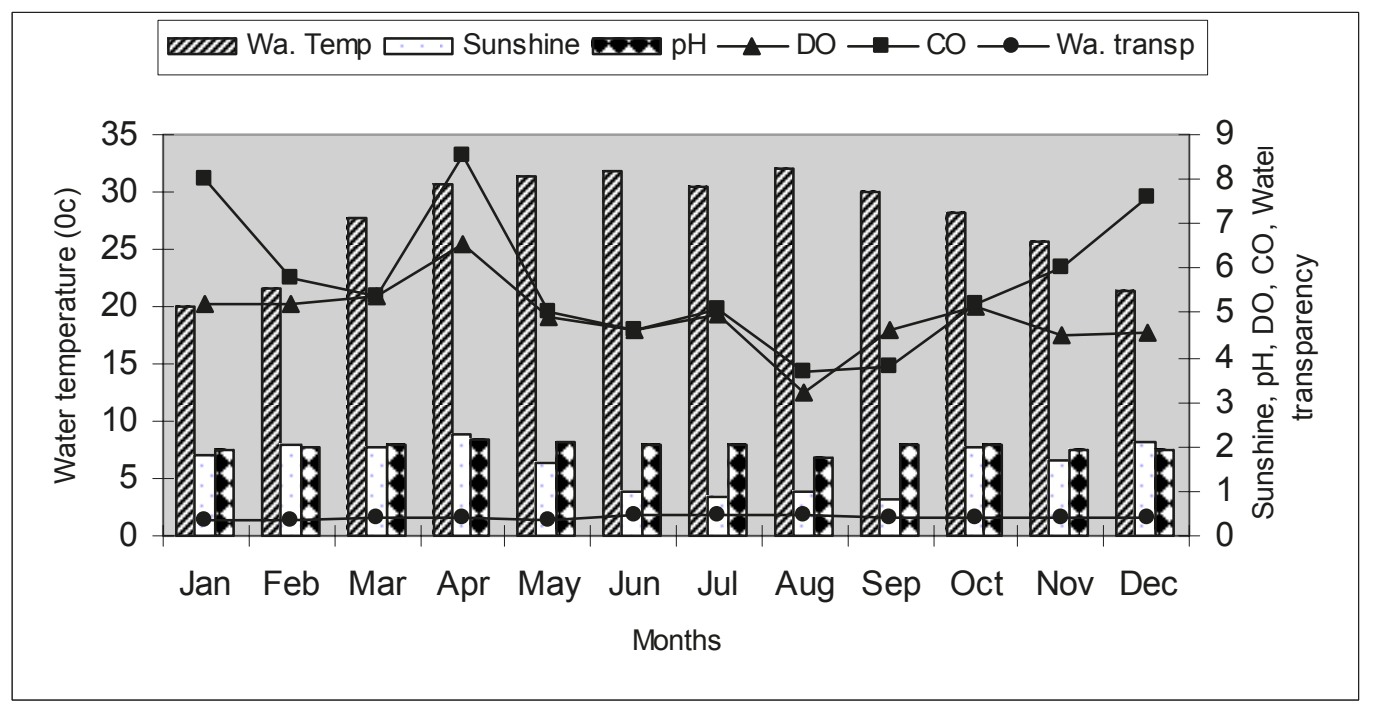

Fig. 2. Physico-chemical parameters of ponds located in Rajshahi University Campus during 1995

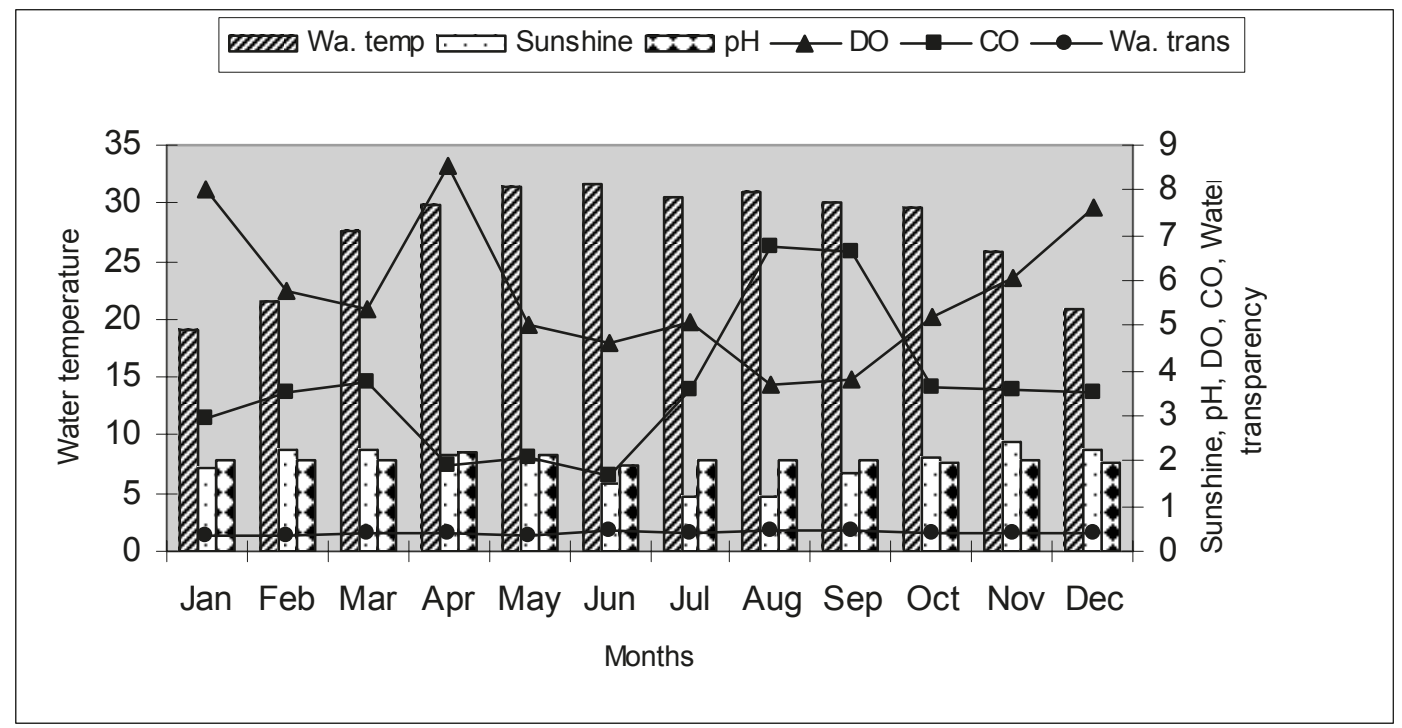

Fig. 3. Physico-chemical parameters of ponds located in Rajshahi University Campus during 1996

month and season. The mean values of different physico-chemical parameters of 1995 and 1996 of different ponds are shown in Figs. 2 and 3, while the conditions of ditches and irrigated paddy fields are shown in Tables I and II. Relationships between environmental factors prevailed in ponds and abundance of B. bengalensis are shown in Table III.

The physico-chemical conditions of ponds, ditches and irrigated paddy fields more or less varied with the change of month and season. The mean values of different physico-chemical parameters of 1995 and 1996 of different ponds are shown in Figs. 2 and 3, while the conditions of ditches and irrigated paddy fields are shown in Tables I and II. Relationships between environmental factors prevailed in ponds and abundance of B. bengalensis are shown in Table III.

The present observation reveals that the annual air temperature cycle maintains a close parallel relationship with the annual cycle of water temperature. The temperature of all the waterbodies studied usually declined from November and reached minimum in January and thereafter increased steadily from April to September (Figs. 2 and 3 and Tables I and II). Minimum $\left(18.98{ }^{\circ} \mathrm{C}\right)$ and maximum $\left(32.08{ }^{\circ} \mathrm{C}\right)$ water temperature of ponds were determined in the months of 
Table I. Physico-chemical parameters of ditches of Rajshahi University Campus during 1995 and 1996

\begin{tabular}{|c|c|c|c|c|c|c|c|c|c|c|}
\hline \multirow[t]{2}{*}{ Months } & \multicolumn{2}{|c|}{$\begin{array}{l}\text { Water temperature } \\
\left({ }^{\mathrm{O}} \mathrm{c}\right)\end{array}$} & \multicolumn{2}{|c|}{$\begin{array}{l}\text { Water tranaparency } \\
(\mathrm{cm})\end{array}$} & \multicolumn{2}{|c|}{$\mathrm{pH}$} & \multicolumn{2}{|c|}{$\begin{array}{c}\text { Dissolved oxygen } \\
(\mathrm{mg} / \mathrm{l})\end{array}$} & \multicolumn{2}{|c|}{$\begin{array}{l}\text { Dissolved carbon } \\
\text { dioxide }(\mathrm{mg} / \mathrm{l})\end{array}$} \\
\hline & 1995 & 1996 & 1995 & 1996 & 1995 & 1996 & 1995 & 1996 & 1995 & 1996 \\
\hline Jul & $\begin{array}{l}30.55 \pm \\
0.90\end{array}$ & $\begin{array}{l}30.43 \pm \\
1.09\end{array}$ & $\begin{array}{l}0.38 \pm \\
0.13\end{array}$ & $\begin{array}{l}0.40 \pm \\
0.14\end{array}$ & $\begin{array}{l}7.82 \pm \\
0.07\end{array}$ & $\begin{array}{l}7.97 \pm \\
0.11\end{array}$ & $\begin{array}{l}3.12 \pm \\
0.33\end{array}$ & $\begin{array}{l}2.95 \pm \\
0.25\end{array}$ & $\begin{array}{l}14.66 \pm \\
1.39\end{array}$ & $\begin{array}{l}13.42 \pm \\
1.17\end{array}$ \\
\hline Aug & $\begin{array}{l}30.59 \pm \\
0.89\end{array}$ & $\begin{array}{l}31.10 \pm \\
1.01\end{array}$ & $\begin{array}{l}0.39 \pm \\
0.05\end{array}$ & $\begin{array}{l}0.45 \pm \\
0.06\end{array}$ & $\begin{array}{l}7.80 \pm \\
0.11\end{array}$ & $\begin{array}{l}7.70 \pm \\
0.27\end{array}$ & $\begin{array}{l}3.20 \pm \\
0.31\end{array}$ & $\begin{array}{l}3.23 \pm \\
0.3\end{array}$ & $\begin{array}{l}13.95 \pm \\
1.58\end{array}$ & $\begin{array}{l}12.28 \pm \\
0.6\end{array}$ \\
\hline Sep & $\begin{array}{l}29.89 \pm \\
0.99\end{array}$ & $\begin{array}{l}31.74 \pm \\
0.51\end{array}$ & $\begin{array}{l}0.36 \pm \\
0.08\end{array}$ & $\begin{array}{l}0.39 \pm \\
0.09\end{array}$ & $\begin{array}{l}7.84 \pm \\
0.07\end{array}$ & $\begin{array}{l}7.87 \pm \\
0.01\end{array}$ & $\begin{array}{l}3.09 \pm \\
0.31\end{array}$ & $\begin{array}{l}2.55 \pm \\
0.25\end{array}$ & $\begin{array}{l}14.19 \pm \\
2.17\end{array}$ & $\begin{array}{l}12.15 \pm \\
28\end{array}$ \\
\hline Oct & $\begin{array}{l}28.18 \pm \\
1.0\end{array}$ & $\begin{array}{l}28.54 \pm \\
0.5\end{array}$ & $\begin{array}{l}0.33 \pm \\
0.2\end{array}$ & $\begin{array}{l}0.36 \pm \\
0.13\end{array}$ & $\begin{array}{l}7.85 \pm \\
0.06\end{array}$ & $\begin{array}{l}7.95 \pm \\
0.04\end{array}$ & $\begin{array}{l}3.14 \pm \\
0.32\end{array}$ & $\begin{array}{l}3.11 \pm \\
0.29\end{array}$ & $\begin{array}{l}13.45 \pm \\
2.3\end{array}$ & $\begin{array}{l}12.89 \pm \\
1.31\end{array}$ \\
\hline Nov & $\begin{array}{l}23.21 \pm \\
1.12\end{array}$ & $\begin{array}{l}22.44 \pm \\
0.49\end{array}$ & - & - & $\begin{array}{l}7.83 \pm \\
0.05\end{array}$ & $\begin{array}{l}7.75 \pm \\
0.02\end{array}$ & $\begin{array}{l}3.02 \pm \\
0.36\end{array}$ & $\begin{array}{l}2.27 \pm \\
0.24\end{array}$ & $\begin{array}{l}14.71 \pm \\
2.21\end{array}$ & $\begin{array}{l}12.33 \pm \\
1.15\end{array}$ \\
\hline Dec & $\begin{array}{l}20.38 \pm \\
0.92\end{array}$ & $\begin{array}{l}19.5 \pm \\
0.22\end{array}$ & - & - & $\begin{array}{l}7.71 \pm \\
0.05\end{array}$ & $\begin{array}{l}7.74 \pm \\
0.08\end{array}$ & $\begin{array}{l}3.08 \pm \\
0.29\end{array}$ & $\begin{array}{l}3.0 \pm \\
0.2\end{array}$ & $\begin{array}{l}15.74 \pm \\
1.65\end{array}$ & $\begin{array}{l}15.57 \pm \\
3.56\end{array}$ \\
\hline Jan & $\begin{array}{l}17.91 \pm \\
1.13\end{array}$ & $\begin{array}{l}18.0 \pm \\
1.0\end{array}$ & - & - & $\begin{array}{l}7.62 \pm \\
1.16\end{array}$ & $\begin{array}{l}7.61 \pm \\
0.04\end{array}$ & $\begin{array}{l}3.05 \pm \\
0.25\end{array}$ & $\begin{array}{l}2.92 \pm \\
0.22\end{array}$ & $\begin{array}{l}15.53 \pm \\
2.23\end{array}$ & $\begin{array}{l}16.14 \pm \\
1.04\end{array}$ \\
\hline $\begin{array}{l}\text { Mean } \pm \\
\text { SD }\end{array}$ & $\begin{array}{l}25.82 \\
\pm 4.87\end{array}$ & $\begin{array}{l}25.96 \pm \\
5.4\end{array}$ & $\begin{array}{l}0.37 \pm \\
0.02\end{array}$ & $\begin{array}{l}0.4 \pm \\
0.03\end{array}$ & $\begin{array}{l}7.78 \pm \\
0.08\end{array}$ & $\begin{array}{l}7.8 \pm \\
0.12\end{array}$ & $\begin{array}{l}3.1 \pm \\
0.06\end{array}$ & $\begin{array}{l}2.86 \pm \\
0.31\end{array}$ & $\begin{array}{l}14.6 \pm \\
0.76\end{array}$ & $\begin{array}{l}13.54 \pm \\
1.53\end{array}$ \\
\hline
\end{tabular}

Table II. Physico-chemical parameters of irrigated paddy fields located in Rajshahi University Campus during 1995 and 1996

\begin{tabular}{|c|c|c|c|c|c|c|c|c|}
\hline \multirow[t]{2}{*}{ Months } & \multicolumn{2}{|c|}{ Water temperature $\left({ }^{\mathrm{O}} \mathrm{C}\right)$} & \multicolumn{2}{|c|}{$\mathrm{pH}$} & \multicolumn{2}{|c|}{ Dissolved oxygen (mg/l) } & \multicolumn{2}{|c|}{$\begin{array}{l}\text { Dissolved carbon dioxide } \\
\qquad(\mathrm{mg} / \mathrm{l})\end{array}$} \\
\hline & 1995 & 1996 & 1995 & 1996 & 1995 & 1996 & 1995 & 1996 \\
\hline May & $31.69 \pm 0.18$ & $31.58 \pm 0.25$ & $8.2 \pm 0.21$ & $8.22 \pm 0.32$ & $4.88 \pm 2.68$ & $4.89 \pm 1.54$ & $4.15 \pm 2.05$ & $4.13 \pm 2.12$ \\
\hline Jun & $29.56 \pm 0.23$ & $29.48 \pm 0.42$ & $8.2 \pm 0.12$ & $8.24 \pm 0.15$ & $4.92 \pm 2.31$ & $4.95 \pm 1.13$ & $4.11 \pm 2.13$ & $4.09 \pm 1.88$ \\
\hline Jul & $31.6 \pm 0.19$ & $31.49 \pm 0.28$ & $8.23 \pm 0.16$ & $8.29 \pm 0.19$ & $5.15 \pm 0.68$ & $5.25 \pm 1.92$ & $3.45 \pm 0.62$ & $3.22 \pm 2.07$ \\
\hline Aug & $30.23 \pm 0.32$ & $30.18 \pm 0.47$ & $7.89 \pm 0.19$ & $7.93 \pm 0.24$ & $4.98 \pm 2.12$ & $4.99 \pm 2.19$ & $7.31 \pm 2.08$ & $7.3 \pm 2.18$ \\
\hline Sep & $29.82 \pm 1.12$ & $29.61 \pm 1.19$ & $7.6 \pm 0.56$ & $7.67 \pm 0.49$ & $4.85 \pm 1.82$ & $4.9 \pm 2.08$ & $7.36 \pm 2.05$ & $7.31 \pm 2.17$ \\
\hline Oct & $28.19 \pm 1.49$ & $28.10 \pm 1.14$ & $7.48 \pm 0.27$ & $7.53 \pm 0.81$ & $4.79 \pm 1.74$ & $4.86 \pm 1.83$ & $7.41 \pm 0.98$ & $7.36 \pm 2.18$ \\
\hline $\begin{array}{l}\text { Mean } \\
\pm \mathrm{SD}\end{array}$ & $30.18 \pm 1.21$ & $30.07 \pm 1.21$ & $7.93 \pm 0.3$ & $7.98 \pm 0.3$ & $4.93 \pm 0.12$ & $4.97 \pm 0.13$ & $5.63 \pm 1.74$ & $5.57 \pm 1.78$ \\
\hline
\end{tabular}

January during 1996 and August during 1995, respectively. Maximum water temperature during summer months was reported by Ismail et al. (1984) in Dhaka and minimum water temperature during winter by Begum et al. (1994).

Maximum (0.46 cm in 1995 and $0.48 \mathrm{~cm}$ in 1996) and minimum $(0.35 \mathrm{~cm}$ in 1995 and $0.34 \mathrm{~cm}$ in 1996) values of transparency were determined in August and May, respectively in pond during the present observation (Figs. 2 and 3). Boycott (1934) concluded that the chief considerations for aquatic molluscs were clean and transparent water in Britain.
The minimum rainfall $(1.24 \mathrm{~cm})$ of the campus was recorded in the month of December, 1995 while the maximum $(370.95 \mathrm{~cm})$ was in the month of September, 1995. The mean values of rainfall were calculated as $123.36 \mathrm{~cm}$ and $105.75 \mathrm{~cm}$ in 1995 and 1996, respectively. The three months (January, November and December) of 1996 experienced no rainfall during the study period.The range of sunshine during the present study in two years was recorded as 3.10 to $9.43(6.82 \pm 0.60)$ hours per day (Fig. 2 and 3). 
Table III. Relationships between environmental factors prevailed in ponds and abundance of Bellamya bengalensis located in Rajshahi University Campus during 1995 and 1996

\begin{tabular}{|c|c|c|c|c|c|c|}
\hline Factors & Year & $\begin{array}{c}\text { Value of } \\
\text { a }\end{array}$ & $\begin{array}{c}\text { Value of } \\
b\end{array}$ & $\begin{array}{c}\text { Correlation } \\
\text { coefficient } \\
\text { (r) }\end{array}$ & $\begin{array}{r}\text { Reamrks } \\
(+/-)\end{array}$ & $\begin{array}{c}\text { Significant } \\
\text { at }\end{array}$ \\
\hline $\begin{array}{c}\text { Water } \\
\text { temperature }\end{array}$ & 1995 & 53.27 & -0.089 & 0.097 & - & $\mathrm{p}<0.05$ \\
\hline $\begin{array}{c}\text { and } \\
\text { abundance }\end{array}$ & 1996 & 30.46 & -0.026 & 0.379 & - & , \\
\hline Transparency & 1995 & 0.419 & -1.1905 & 0.187 & - & , \\
\hline $\begin{array}{c}\text { and } \\
\text { abundance }\end{array}$ & 1996 & 0.405 & 0.0004 & 0.066 & - & , \\
\hline Rainfall and & 1995 & 294.04 & -1.32 & 0.558 & - &, \\
\hline abundance & 1996 & 235.49 & -0.972 & 0.531 & - & , \\
\hline Sunshine and & 1995 & 4.106 & 0.0189 & 0.524 & + & , \\
\hline abundance & 1996 & 7.01 & 0.006 & 0.642 & + & , \\
\hline $\mathrm{pH}$ and & 1995 & 7.6 & 0.003 & 0.217 & - & , \\
\hline abundance & 1996 & 7.84 & -0.001 & 0.003 & - & , \\
\hline DO and & 1995 & 5.03 & -1.338 & 0.1002 & - & , \\
\hline abundance & 1996 & 3.80 & 0.014 & 0.583 & - & , \\
\hline $\mathrm{CO}$ and & 1995 & 6.56 & -9.55 & 0.255 & - & ", \\
\hline abundance & 1996 & 5.33 & -0.012 & 0.505 & - & , \\
\hline
\end{tabular}

The observed $\mathrm{pH}$ of water of ponds studied ranged from 6.83 to 8.48 (Figs. 2 and 3). The $\mathrm{pH}$ of freshwater habitats in different regions of the globe ranged from 6.0 to 9.3 depending on the nature of the habitats and variations of seasons (Hubendick, 1951; Patnaik and Ray, 1968; and Ali et al., 1980). Hubendick (1951) opined that pH was intricately entangled in the complex biological system of a body of water and indirectly its snail fauna.

Maximum dissolved oxygen $(8.52 \mathrm{mg} / \mathrm{l})$ was recorded in April of 1996 and minimum $(3.19 \mathrm{mg} / \mathrm{l}$ and $3.7 \mathrm{mg} / \mathrm{l})$ in August of 1995 and 1996 in the ponds of University Campus (Figs. 2 and 3). This maximum record is supported by Ali et al. (1980) in Tongi, Dhaka. Minimum dissolved oxygen in freshwater habitats was recorded (Islam et al., 1979; Ismail et al., 1984; Begum et al., 1994) in the month of January.

Maximum dissolved carbon dioxide (9.83 $\mathrm{mg} / \mathrm{l})$ was determined in August of 1995 and minimum (1.67 mg/l) in June of 1996 in different ponds (Figs. 2 and 3). Khondaker and Parveen (1992) recorded maximum carbon dioxide (7.4 $\mathrm{mg} / \mathrm{l})$ in October from Kaptai lake.
Breeding in snails like Vivipara bengalensis, Melanoides tuberculatus, Bulinus globosa, B. uganda, Bithynia tentaculata generally starts just after the onset of rains (Annandale and Sewell, 1921; Swell, 1921; Mozley, 1939; Berrie, 1965, 1966; Pike, 1968; Raut, 1980). Raut (1981) concluded that the rate of breeding and fluctuation in the number of snails (Viviparus bengalensis, Lymnaea acuminata, Indoplanorbis exustus) were governed by temperature, rainfall and food. The sunshine is used as a behavioural stimulus for animals and as a timing device to set breeding seasons and other critical events in the life cycles of animals (Krebs, 1985).

\section{Aquatic vegetation}

The aquatic vegetations available in pond, ditch and irrigated paddy field of the study area were of four types (Table IV). The vegetation of the habitats concerned were grouped as submerged, free floating, floating but rooted, and amphibious hydrophytes. Raut (1981) reported that the ponds containing Viviparus bengalensis, Lymnaea acuminata, Indoplanorbis exustus and Acrostoma variabilis had clean water and different kinds of aquatic vegetations viz. Eichhornia 
Table IV. Hydrophytes of Rajshahi University Campus during 1995 and 1996

\begin{tabular}{|c|c|c|c|c|}
\hline \multirow[t]{2}{*}{ Name of the hydrophytes } & \multirow{2}{*}{ Submerged } & \multicolumn{2}{|c|}{ Floa ting } & \multirow{2}{*}{ Amphibious } \\
\hline & & Free floating & Floating but rooted & \\
\hline Ceratophyllum demersum (L. 1753) & + & & & \\
\hline Hydrilla verticillata (Royle 1839) & + & & & \\
\hline Vallisneria spiralis (L. 1753) & + & & & \\
\hline Azolla pinnata (R. Br. 1810) & & + & & \\
\hline Eichhornia crassipes (Mart.) Solms 1883 & & + & & \\
\hline Lemna perpusilla (Torrey 1843) & & + & & \\
\hline Nechamandra alternifolia (Roxb.) Thw. & & + & & \\
\hline 1864 & & & & \\
\hline Pistia stratiotes (L. 1753) & & + & & \\
\hline Utricularia stellaris (L. 1753) & & + & & \\
\hline Wolffia arrhiza (L.) Horkel ex Wimmer & & + & & \\
\hline 1857 & & & & \\
\hline Aponogeton appendiculatus (Bruggen & & & + & \\
\hline 1968$)$ & & & & \\
\hline Blyxa amberti (Rich. 1812) & & & + & \\
\hline Ludwigia adscendens (L.) Hara 1953 & & & + & \\
\hline Nymphaea nouchali (Burm. f. 1768) & & & + & \\
\hline N. stellata (Willd. 1799) & & & + & \\
\hline Nymphoides cristatum (Roxb.) O. Kuntze & & & + & \\
\hline 1891 & & & & \\
\hline Najas graminea (Del. 1812) & & & + & \\
\hline Pomatogeton mucronatus (Presl. 1893) & & & + & \\
\hline Ottelia alismoides (L.) Pers. 1805 & & & + & \\
\hline Alternanthera philoxeroides (Mart.) & & & & + \\
\hline Griseb. 1879 & & & & \\
\hline A. sessilis (L. 1753) & & & & + \\
\hline Cyperus playtystylis (R. Br. 1810) & & & & + \\
\hline C. tegetiformis (Roxb. 1814) & & & & + \\
\hline C. articulatus (L. 1753) & & & & + \\
\hline Limnophila sessiliflora (Blume 1826) & & & & + \\
\hline L. cana (Griff. 1851) & & & & + \\
\hline Leptochloa chinensis (L.) Nees & & & & + \\
\hline Monochoria hastata (L.) Solms 1883 & & & & + \\
\hline Marsilea sp.(L. 1753) & & & & + \\
\hline Polygonum barbatum (L. 1753) & & & & + \\
\hline P. lanatum (Roxb. 1832) & & & & + \\
\hline Sporobolus indicus (L. 1753) & & & & + \\
\hline Schoenoplectus grossus (L.f.) Palla 1911 & & & & + \\
\hline S. articulatus (L.) Palla 1889 & & & & + \\
\hline Ipomoea aquatica (Forsk. 1775) & & & & + \\
\hline & 03 & 07 & 09 & 16 \\
\hline
\end{tabular}


speciosa, Pistia sylvestris, Uncaria sp., Nuphar sp., Trapa bispinosa, Vallisneria spiralis and several other hydrophytes. Patnaik and Ray (1968) worked on Lymnaea auricularia whose findings agree with this study.

\section{Abundance}

$B$. bengalensis was found to be the most abundant gastropod species of different waterbodies of Rajshahi University Campus throughout the study period. Its abundance varied from 30 to $245 / \mathrm{m}^{2}$ with a mean of $124.58 \pm 58.93 / \mathrm{m}^{2}$ in 1995 and from 40 to $255 / \mathrm{m}^{2}$ with a mean of $133.33 \pm 60.84 / \mathrm{m}^{2}$ in 1996 (Fig. 4). Two distinct peaks of abundance were recorded in both the years, the first in April and the second in October. The pattern of population fluctuation was nearly similar in both the years except that in the second year, the abundance as a whole was higher when compared to the first year. Mahapatra (1984) and Gupta (1989) recorded that there was only one peak in most of the snails in West Bengal and some parts of India and this was confined to monsoon through pre-monsoon and post-monsoon, respectively. Aldridge and McMahon (1978) reported that Corbicula maniliensis showed maximum density per $\mathrm{m}^{2}$ for spring generation $\left(26.6 / \mathrm{m}^{2}\right)$ in 1975 and fall generation $\left(55.0 / \mathrm{m}^{2}\right)$ in 1975 occurred in late September and late November, respectively. The abundance of $\mathrm{B}$. bengalensis exhibited negative correlation with water temperature, water transparency, rainfall, $\mathrm{pH}, \mathrm{DO}$ and $\mathrm{CO}_{2}$, but having positive correlation with sunshine (Table III).

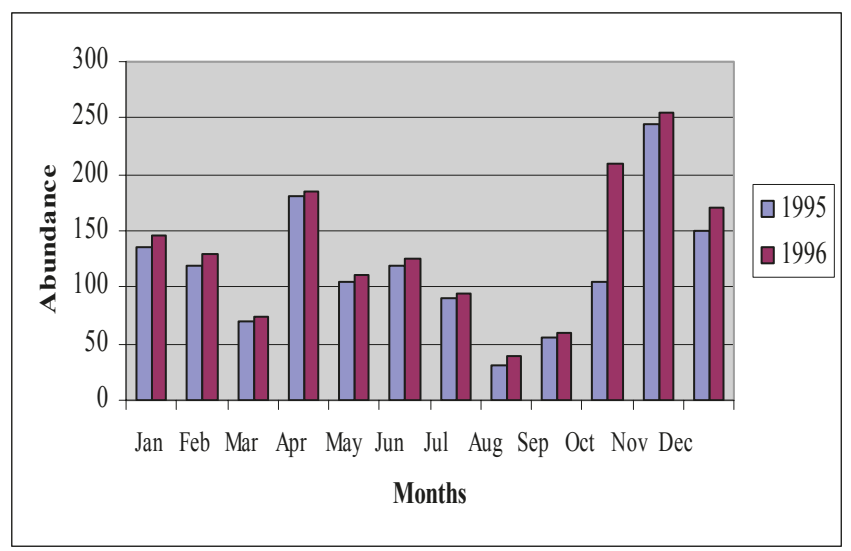

Fig. 4. Abundance of Bellamya bengalensis located in ponds of Rajshahi University Campus

\section{Conclusion}

The present investigation on the ecology of B. bengalensis in Rajshahi University Campus has brought information on their habitats of ponds and other water bodies. Although $B$. bengalensis is herbivorous and completely aquatic, the snail occupies the permanent waterbodies as well as temporary ditches and irrigated paddy fields provided with food plants and other requisite physico- chemical components of the environment. Turbid water with suspended inorganic matter and deep water without much aquatic vegetation appeared to be unfavourable. The influence of each conditioning the habitats appeared to be interrelated. Abundance of $B$. bengalensis showed positive correlation with the sunshine. The snail is the most abundant species in different waterbodies of Rajshahi University Campus.

\section{References}

Aldridge DW and McMohan RF (1978), Growth, fecundity and bioenergetics in a natural population of the Asiatic freshwater clam, Corbicula maniliensis, Philippi, from North Central Texas, $J$. moll. Stud. 44: 49-70.

Ali S and Chakraborty T (1992), Bangladesh Mitha Panir Amerudandi Prani (A book on Freshwater Invertebrates of Bangladesh), I ${ }^{\text {st }}$ Ed., Bangla Academy, Dhaka, Bangladesh, p 208.

Ali S, Chowdhury A and Roy AR (1980), Ecology and seasonal abundance of zooplankton in a pond in Tongi, Dhaka, Bangladesh J. Zool. 8(1): 41-48.

Annandale N and Sewell RBS (1921), The banded pond snails of India (Vivipara bengalensis), Rec. Indian Mus. 22: 215-292, pls. 1-111.

APHA (1989), Standard Methods for the examination of water and waste water, American Public Health Association, Washington, pp 3-58.

Begum S, Chowdhury AN and Sultana N (1994), Physico-chemical parameters of a semi-intensive managed fish pond, Bangla. J. Sci. Res. 12(1): 115-119.

Berrie AD (1965), On the life of Lymnaea stagnalis (L.) in the west of Scotland, Proc. malac. Soc. Lond. 36: 283-295.

Berrie AD (1966), Growth and seasonal variation in reproductive organs of Lymnaea stagnalis (L.), Proc. malac. Soc. Lond. 37: 83-92.

Boycott AE (1934), The habitats of freshwater Mollusca in Britain, J. Ecol. 27: 116-186, 70. 
Gupta BD (1989), Seasonal variation of snail population and their infection with trematode parasites In: Snails, flukes and man, Ed. Jairajpuri MS, Zool. Surv. India, Calcutta, p 67.

Hanifa ML (1978), Secondary productivity and energy flow in a tropical pond, Hydrobiologia 59: 49-66.

Hubendick B (1951), Recent Lymnaeidae: Their variation, morphology, taxonomy, nomenclature and distribution, Küngliga Svenska Vetenskapsakademiens Handlingar 3: 1-223.

Islam AKMN, Rahman M and Chowdhury AR (1979), Hydrobiological studies of Dhanmondi lake in Dhaka, Bangladesh J. Asiat. Soc. Sci. 5(1): 59-75.

Ismail M, Rahman R, Ali S and Ahmed KH (1984), Studies on limnology and some aspects of biology of Oreochromis nilotica (L.) in a pond, Jurain, Dhaka, Proc. Fourth Nat. Zool. Conf. Bangladesh, pp 97-105.

Jahan MS (1993), Some terrestrial and freshwater gastropods of Bangldesh with their ecological notes, Univ.j. zool. Rajshahi Univ. 12: 65-71.

Khan M S and Halim M (1987), Aquatic Angiosperms of Bangladesh. Bangladesh National Herbarium, Bangladesh Agricultural Research Council, Dhaka, p 120 .

Khondakar M and Parveen L (1992), Study on the physical and chemical limnology of a shallow, hypertrophic artificial lake, Bangla. J. Sci. Res. 10(1): 9-16.

Khan RA and Chaudhuri S (1984), The population and production ecology of a freshwater snail, Bellamya bengalensis (Lamarck) (Gastropoda: Viviparidae) in an artificial lake of Calcutta, India, Bull. Zool. Surv. India 5(2\&3): 59-76.

Kreb CJ (1985), Ecology, Harper Collins Publishers Inc., p 800.

Mahapatra D (1984), Seasonal variation of snail population and their infection with trematode parasites In: Snails, flukes and man, Ed. Jairajpuri MS, Zool. Surv. India, Calcutta, p 67.

Michael RG (1968), Studies on the bottom fauna in a tropical freshwater fish pond, Hydrobiologia 31: 203-230.

Mozley A (1939), The freshwater mollusca of Tanganyika Territory and Zanzibar protectorate and their relation to human schistosomiasis, Trans. Roy. Soc. Edinb. 59: 687.
Patnaik MM and Ray SK (1968), Studies on geographical distribution and ecology of Lymnaea auricularia var. rufescens, the intermediate host of Fasciola gigantica in Orissa, Indian J. Vet. Sci. 32: 3.

Pike AW (1968), The distribution and incidence of larval trematodes in the freshwater fauna of the Wentloog level, South Wales, J. Zool. London 155: 293-309.

Prashad B (1925), Anatomy of the common Indian apple snail, Pila globosa, Mem. Indian Mus. 8: 91-153.

Raut SK (1980), Preliminary observations on the breeding of the banded snail, Viviparus bengalensis (Lamarck) (Gastropoda:Viviparidae) in West bengal, Bull. zool. Surv. India 3: 47-50.

Raut SK (1981), Sex ratio in Viviparus bengalensis (Lamarck) Gastropoda:Viviparidae), Bull. zool. Surv. India 4(1): 13-15.

Subba Rao NV (1989), Handbook of Freshwater Molluscs of India, Ed. Director, Zool. Surv. India, Calcutta, p 289.

Subramanyam K (1962), Aquatic Angiosperms. I.C.S.I.R., Delhi, India, p 198.

Sewell RBS (1921), The Banded pond snail of India (Vivipara bengalensis), Part-1, Anatomical, Rec. Indian Mus. 22: 529-548.

Welch PS (1948), Limnological Methods, McGraw-Hill, New York, p 381.

Received: 3 October 2016; Revised: 30 October 2016; Accepted: 28 December 2016. 